\title{
Alpha-1-Antitrypsin and a Broad Spectrum Metalloprotease Inhibitor, RS113456, Have Similar Acute Anti-Inflammatory Effects
}

\author{
Andrew Churg, Jin Dai, Katalin Zay, Aly Karsan, Richard Hendricks, Calvin Yee, \\ Robert Martin, Rebecca MacKenzie, Changshi Xie, Li Zhang, Stephen Shapiro, and \\ Joanne L. Wright \\ Department of Pathology (AC, JD, KZ, AK, CX, LZ, JLW), University of British Columbia, Vancouver, British \\ Columbia; Roche Bioscience (RH, CY, RM, RMac), Palo Alto, California; and Department of Medicine (SS), \\ Washington University School of Medicine, St. Louis, Missouri
}

\begin{abstract}
SUMMARY: There is increasing evidence that antiproteases are able to affect the inflammatory response. To further examine this question, we administered human $\alpha$-1-antitrypsin ( $\alpha 1 \mathrm{AT}$ ) or a synthetic metalloprotease inhibitor (RS113456) to C57 mice followed by a single intratracheal dose of quartz, a dust that evokes a marked, lasting, polymorphonuclear leukocyte (PMN) infiltrate. At 2 hours after dust administration, both antiproteases completely suppressed silica-induced PMN influx into the lung and macrophage inflammatory protein-2 (MIP-2)/monocyte chemotactic protein-1 (MCP-1) (neutrophil/macrophage chemoattractant) gene expression, partially suppressed nuclear transcription factor $\kappa \mathrm{B}(\mathrm{NF}-\kappa \mathrm{B})$ translocation, and increased inhibitor of NF- $\kappa \mathrm{B}\left(I_{\kappa} \mathrm{B}\right)$ levels. By 24 hours, PMN influx and connective tissue breakdown measured as lavage desmosine or hydroxyproline were still at, or close to, control levels after antiprotease treatment, and increases in NF- $\kappa$ B translocation and MIP-2/MCP-1 gene expression were variably suppressed. At both time points, neither agent prevented silica-induced increases in amount of whole lung MIP-2 or MCP-1 protein, but both did prevent increases in whole lung intercellular adhesion molecule-1 (ICAM-1) at 24 hours. Inactivating the $\alpha 1 \mathrm{AT}$ by oxidation to the point that it no longer possessed antiproteolytic properties did not affect its ability to suppress inflammation. Both antiproteases also prevented the silica-induced acute inflammatory response in mice with knocked out genes for macrophage metalloelastase (MME -/-), mice that develop inflammation, but not connective tissue breakdown, and the pattern of $\alpha 1 \mathrm{AT}$ breakdown fragments was identical in control and MME $-/-$ animals. These findings suggest that, in this model of acute PMN mediated inflammation, a serine protease inhibitor and a metalloprotease inhibitor have similar anti-inflammatory properties, that inflammation is not mediated by proteolysis with generation of chemotactic matrix fragments, and that classic antiproteolysis (complexing of protease to antiprotease) probably does not play a role in suppression of inflammation. The antiproteolytic effects of these agents do not seem to be mediated by protection of endogenous $\alpha 1$ AT. (Lab Invest 2001, 81:1119-1131).
\end{abstract}

$$
T^{\text {hen }}
$$
he traditional view of antiproteases is that their important and principal function is to complex with and inhibit various types of proteases and thus prevent or down-regulate proteolytic tissue injury. However, a number of years ago it was observed that elastin and collagen fragments, fragments produced by proteolytic action, were in themselves chemoattractants (Senior et al, 1980, 1989). This observation suggested that complexing of antiproteases with their substrates might act, not only to directly inhibit proteolysis, but also to prevent inflammatory cell influxes by preventing formation of chemotactic matrix fragments.

It has subsequently become apparent that the role of antiproteases in preventing or modulating tissue

Received April 12, 2001.

Supported by grants from the Canadian Institutes of Health Research and a grant from the Bayer Blood Partnership.

Address reprint requests to: Dr. Andrew Churg, Department of Pathology, University of British, Columbia, 2211 Wesbrook Mall, Vancouver, BC, CanadaV6T2B5. E-mail: achurg@interchange.ubc.ca injury is considerably more complicated. The serine protease inhibitor, secretory leukoprotease inhibitor (SLPI), seems to suppress prostaglandin $E_{2}\left(P E_{2}\right)$ and metalloprotease production in monocytes (Zhang et al, 1997) and also antagonizes up-regulation of nuclear transcription factor $\kappa \mathrm{B}(\mathrm{NF}-\kappa \mathrm{B})$ and downstream genes induced in macrophages by lipopolysaccharide (LPS) (Jin et al, 1997). Ashcroft et al (2000) found that SLPI seems to play a crucial role in normal wound healing. Kikuchi et al (2000) noted that both SLPI and $\alpha$-1-antitrypsin (alpha-1-antiproteinase, $\alpha 1 \mathrm{AT})$ augmented hepatocyte growth factor production in cultured human lung fibroblasts. Lentsch et al (1999) showed that SLPI attenuated the acute inflammatory response caused by deposition of IgG immune complexes in the lung. In this model, SLPI decreased neutrophil infiltration by about $40 \%$ and decreased extravascular serum leakage, ameliorated vascular intercellular adhesion molecule-1 (ICAM-1) upregulation, and reduced $\mathrm{NF}-\kappa \mathrm{B}$ activation while increasing inhibitor of $\mathrm{NF}-\kappa \mathrm{B}\left(\mathrm{I}_{\kappa} \mathrm{B}\right)$ levels. 
In a subsequent study, Mulligan et al (2000) examined these effects using SLPI mutants and found that the anti-inflammatory effects of SLPI seemed to correlate with its trypsin inhibitory activity. They suggested that SLPI might be acting by inhibiting an undefined intracellular proteolytic pathway. They also investigated the effects of alpha-1-antitrypsin in the IgG immune complex model and found that it did not behave like SLPI and did not suppress inflammation. However, we (Dhami et al, 2000) observed that $\alpha 1$ AT completely abolished the acute inflammatory infiltrate and connective tissue breakdown (measured as lavage desmosine, DES, a marker of elastin breakdown, and lavage hydroxyproline, $\mathrm{HP}$, a marker of collagen breakdown) produced by cigarette smoke, suggesting that $\alpha 1$ AT might well have anti-inflammatory properties. It is interesting in this regard that Stockley et al (1990) reported that $\alpha 1 \mathrm{AT}$ directly inhibited neutrophil chemotaxis.

There is limited evidence that inhibitors of metalloproteases may also have anti-inflammatory properties. Mulligan et al (1993) reported that SLPI and tissue inhibitor of metalloproteinase-2 (TIMP-2) produced approximately equal inhibition of immune complexinduced permeability, hemorrhage, and neutrophil influx, but the decrease in neutrophil influx was modest (about 30\%) compared with the decrease in permeability and hemorrhage. Lentsch et al (1999) found that TIMP-2 did not suppress whole lung NF $-\kappa \mathrm{B}$ activation in a setting where SLPI was effective. Liu et al (2000) recently reported that mice with the gene for gelatinase B knocked out did not develop experimental bullous pemphigoid because the lack of gelatinase $B$ prevented degradation of $\alpha 1 \mathrm{AT}$ and hence protected the animals against the effects of neutrophil elastase. Hautamaki et al (1997) showed that mice lacking macrophage metalloelastase (MME) did not develop emphysema after cigarette smoke exposure and had a greatly reduced inflammatory response to the smoke (see "Discussion").

To further investigate the anti-inflammatory role of antiproteases, in these experiments we used RS113456, a broad spectrum metalloprotease inhibitor that inhibits both human and murine metalloproteases (Abbruzzese et al, 1998), and $\alpha 1 \mathrm{AT}$ (Prolastin, a purified human $\alpha 1 \mathrm{AT}$; Bayer, Etobicoke, Ontario, Canada), in a model of acute silica-induced inflammation. Crystalline silica was administered to C57 or macrophage metalloelastase knockout (MME -/-) mice (see below) as a single intratracheal injection. $\alpha 1$ AT-treated groups were given a single dose of $20 \mathrm{mg}$ of Prolastin 24 hours in advance by ip injection. RS113456-treated animals were given 0.1 $\mathrm{mg} / \mathrm{kg}$ by gavage 1 hour before silica treatment. Silica was used as the inflammatory agent because it produces a long-lasting polymorphonuclear influx in the lung after a single dose. Animals were euthanized at 2 and 24 hours after dust administration, and lavage fluid or lung tissue was obtained.

\section{Results}

Figure 1 shows the basic phenomena seen in the lungs of C57 mice after silica instillation. Within 2 hours there was an increase in lavage polymorphonuclear leukocytes (PMN), and this was more marked by 24 hours. Lavage DES and lavage HP were increased at 24 hours. Pretreatment with either $\alpha 1 \mathrm{AT}$ or RS113456 completely or almost completely prevented the increase in lavage PMN, and completely prevented the increases in DES and HP in these animals. There was no increase in lavage macrophages (MAC) at either time (data not shown).

To examine possible mechanisms behind PMN influx, we looked at levels of NF- $\kappa \mathrm{B}, \mathrm{I}_{\kappa} \mathrm{B}$, and the chemoattractants, macrophage inflammatory protein-2 (MIP-2) and monocyte chemotactic protein-1 (MCP-1), the latter both as a function of gene expression and as a function of protein production. Figure 2 shows Western blots and densitometry for $I_{\kappa} \mathrm{B}, \alpha$ and $\beta$, at 2 hours. Silica significantly depressed $I_{\kappa} \mathrm{B} \alpha$ levels, whereas both protease inhibitors significantly increased $I_{\kappa} \mathrm{B} \alpha$ levels. For $\mathrm{I}_{\kappa} \mathrm{B} \beta$, the decrease in levels with silica treatment was not significant, but there were quite marked increases with antiprotease treatment. Figure 3 shows results at 24 hours. Silica treatment and both antiproteases increased $I_{\kappa} \mathrm{B} \beta$ values above control. Similar results were seen for $I_{\kappa} \mathrm{B} \alpha$, but the silica increase was not significant.

Figure 4 shows gel shifts for $\mathrm{NF}-\kappa \mathrm{B}$ (ie, levels of nuclear NF- $\kappa \mathrm{B}$ ) and corresponding densitometry. Silica produced a marked increase in nuclear $\mathrm{NF}-\kappa \mathrm{B}$ levels at 2 hours, and this effect was ameliorated by about $50 \%$ by pretreatment with antiproteases. At 24 hours, markedly increased nuclear NF- $\kappa \mathrm{B}$ was still present with silica, and there was partial protection with $\alpha 1 \mathrm{AT}$, but not with RS113456.

Figure 5 shows images of reverse transcriptionpolymerase chain reaction (RT-PCR) products for the neutrophil chemoattractant MIP-2 and the macrophage chemoattractant MCP-1. At 2 hours, silica increased gene expression of both of these mediators compared with the control, and both antiproteases suppressed these increases. At 24 hours, silica still increased the levels of both mediators, and there was a variable degree of suppression of gene expression by the antiproteases; for $\alpha 1 \mathrm{AT}$-treated animals, gene expression was clearly increased compared with the 2-hour level.

Figure 6 shows levels of whole lung protein for MIP-2 and MCP-1. MIP-2 and MCP-1 protein levels were markedly increased over control values at both time points.

Figure 7 shows levels of whole lung ICAM-1. This measurement was intended to help determine if antiproteases might suppress factors leading to inflammatory cell adhesion to the endothelium (see "Discussion"). No differences were seen among treatment groups at 2 hours, but by 24 hours silica had produced a small increase in whole lung ICAM-1, and both antiproteases were protective.

To determine whether the traditional active antiproteolytic site of the $\alpha 1 \mathrm{AT}$ molecule is required for anti-inflammatory effects, we gently oxidized the protein until more than $98 \%$ of the original antiprotease activity was abolished, and then reconstituted it to its original protein concentration (see "Materials and 
Effects of $\alpha 1$ AT and RS113456 on Silica-Induced $\mathrm{PMN}$ in Lavage Fluid at $2 \mathrm{Hrs}$

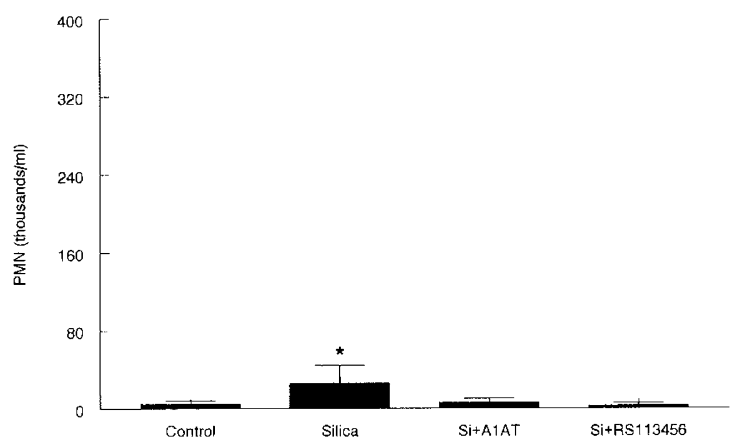

Effects of $\alpha 1$ AT and RS113456 on Silica-Induced Levels of Lavage Desmosine at $24 \mathrm{Hrs}$

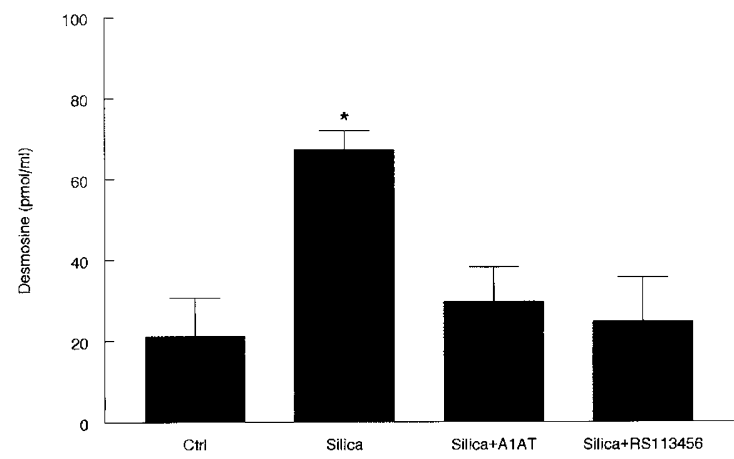

Effects of $\alpha 1 A T$ and RS113456 on Silica-Induced PMN in Lavage Fluid at $24 \mathrm{Hrs}$

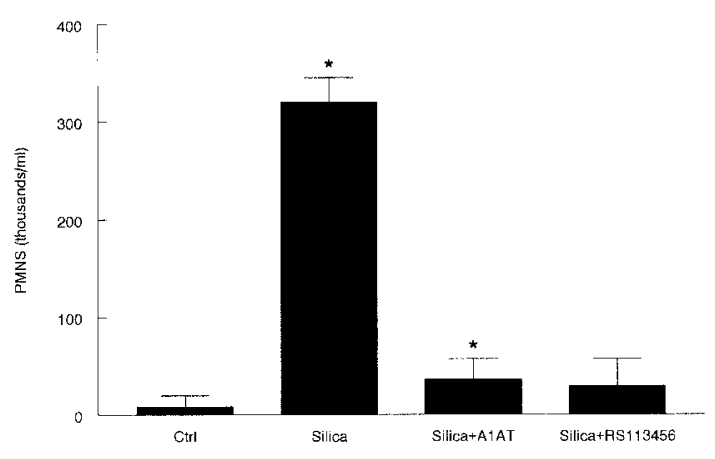

Effects of $\alpha 1$ AT and RS113456 on Silica-Induced Levels of Lavage Hydroxyproline at $24 \mathrm{Hrs}$

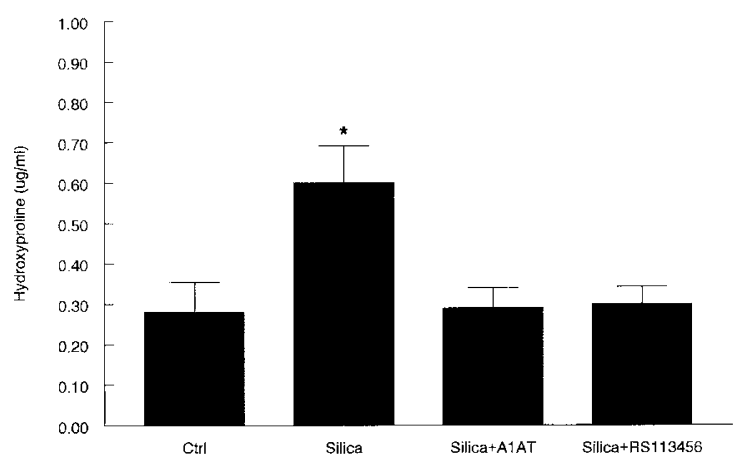

Figure 1.

Effects of $\alpha$-1-antitrypsin ( $\alpha 1 \mathrm{AT}$ ) and a synthetic metalloprotease inhibitor (RS113456) on lavage polymorphonuclear leukocyte (PMN), desmosine, and hydroxyproline. Silica induces an increase in PMN, desmosine, and hydroxyproline, and both antiproteases suppress the silica effect. Values are mean \pm SD. * Significantly greater than control.

Methods"). As shown in Figure 8, the oxidized product was just as effective as the nonoxidized in suppressing PMN influx and had no effect on macrophage numbers (data not shown). To confirm that the protein was oxidized, methionine sulfoxide was assayed by HPLC: no methionine sulfoxide was detected in the original product before oxidation, whereas after oxidation approximately $27 \%$ of the total methionine content was present as methionine sulfoxide. Prolastin, as sold, has a small component of lowermolecular-weight fragments that represent breakdown products of $\alpha 1 \mathrm{AT}$. By densitometry on Western blots, these constitute less than $5 \%$ of the total protein (Fig. 8), and the Western blot confirms that oxidation did not increase the number or intensity of breakdown fragments. These data indicate that the antiproteolytic, but not the anti-inflammatory, effects of $\alpha 1 \mathrm{AT}$ had been largely abolished by oxidation, but without seriously damaging the protein.

To determine whether antiproteases might operate by suppressing protease attack and thus suppressing the generation of chemoattractant matrix fragments $(1,2)$, we administered antiproteases to MME -/mice. As shown in Figure 9, these mice develop an inflammatory infiltrate after silica injection, but do not show evidence of connective tissue breakdown, pre- sumably because the lack of MME is protective. Nonetheless, both antiproteases still protected against the inflammatory influx in MME -/- mice (see "Discussion").

\section{Discussion}

In this paper we have shown that a serine protease inhibitor, $\alpha 1 \mathrm{AT}$, and a metalloprotease inhibitor, RS113456, suppress the acute inflammatory response to silica, an agent that ordinarily evokes a rapid and sustained PMN influx into the lung. However, the pattern of suppression is complex and more than one mechanism is probably involved.

Both antiproteases seem to partially prevent whole lung silica-induced NF- $\kappa \mathrm{B}$ translocation, and to enhance levels of $I_{\kappa} \mathrm{B}$, suggesting that increased $I_{\kappa} \mathrm{B}$ levels are important in preventing NF- $\kappa \mathrm{B}$ activation in this model. Silica is known to acutely decrease cellular I $\kappa$ B levels (Schins et al, 2000), and this effect is seen in our data at 2 hours after silica dust administration, more clearly with $I_{\kappa} \mathrm{B} \alpha$, whereas both antiproteases increase $I \kappa B$ levels. Likewise, at 24 hours there is some variability in the degree to which these two antiproteases prevent NF- $\kappa \mathrm{B}$ translocation. However, these differences may well be dose/time effects, and 
Western Blot - I $\kappa \mathrm{B} \alpha 2 \mathrm{Hrs}$

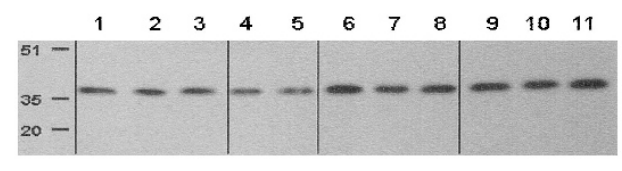

Ctrl Silica $\quad \mathrm{Si}+\mathrm{A} 1 \mathrm{AT}$ Si + RS113
Western Blot - IкB $\beta 2 \mathrm{Hrs}$

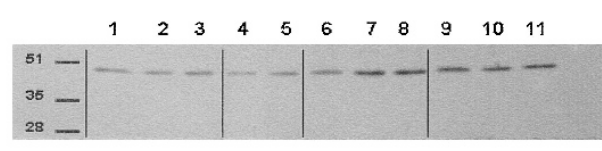

Ctrl Silica $\mathrm{Si}+\mathrm{A} 1 \mathrm{AT} \quad \mathrm{Si}+\mathrm{RS} 113$
Effects of Protease Inhibitors on IKBa Levels 2 Hours After Silica Instillation

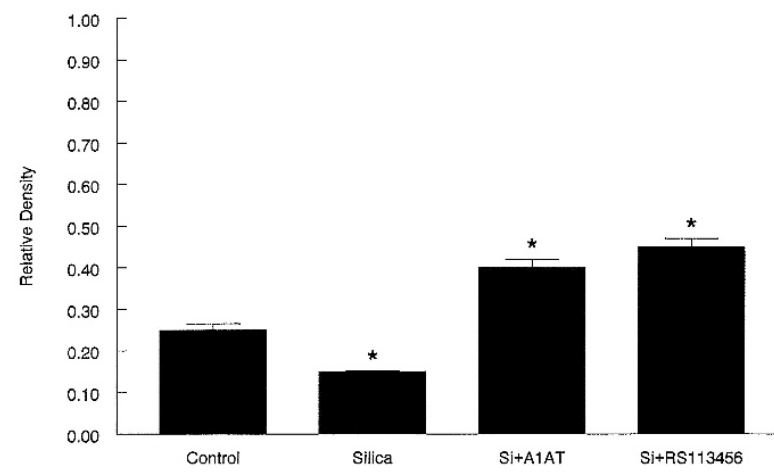

Effects of Protease Inhibitors on IkB $\beta$ Levels 2 Hours After Silica Instillation

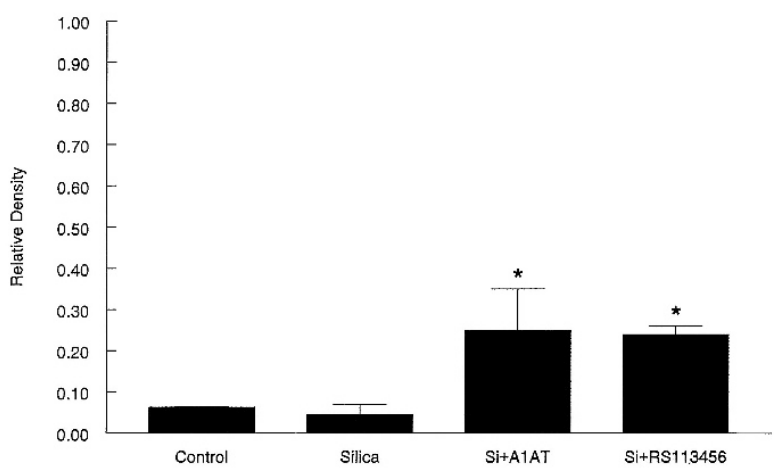

Figure 2.

Effects of $\alpha 1 A T$ and RS113456 on $I_{\kappa} B$ levels at 2 hours in whole lung. Silica drives $I_{\kappa} B$ levels down, whereas both antiproteases increase them. Values are mean $\pm \mathrm{SD} .{ }^{*}$ Significantly greater or less than control.

our intent here was not to decide whether $\alpha 1$ AT was more or less potent than RS113456, but to show, in a broadly qualitative sense, whether or not they produced similar effects (the levels of antiproteases used are arbitrary ones selected simply on the basis of efficacy). The pattern of NF- $\kappa \mathrm{B}$ translocation also does not correspond exactly to the pattern of downstream gene expression (see below), but this may not be surprising, given that two different antiproteases are involved and given recent data that make it clear that $\mathrm{NF}-\kappa \mathrm{B}$ translocation and activation are to a certain extent separate processes with separate mediators (Janssen-Heininger et al, 2000).

Both antiproteases are effective at suppressing gene expression for the PMN chemoattractant MIP-2 and the MAC chemoattractant MCP-1. Both of these genes, which are well documented to be expressed in increased amounts after silica instillation, have NF- $\kappa \mathrm{B}$ recognition sites, and thus it is not surprising that their expression is suppressed in this setting. What is intriguing, however, is that production of increased MIP-2 and MCP-1 protein is not prevented by the antiproteases. The exact reason for this is not clear, but dissociation between gene expression and protein production is not uncommon and may reflect an inflammatory stimulus that causes increased protein release or prolongs the half-life of the mRNA for the protein, all in the absence of new gene transcription. In some systems these differences can be dramatic, both in terms of gene expression versus protein production, and even in terms of differences in the cell types where gene expression or protein production occur. For example, Chleq-Deschamps et al (1993) showed that, in normal human lymphoid tissue, BCL-2 gene expression and BCL-2 protein production are detectable in completely different cells.

Given that we are analyzing whole lungs, questions of different cell type response are certainly relevant. $A$ precedent for dissociation of NF- $\kappa$ B suppression and inflammatory mediator production is evident in the data of Lentsch et al (1999) on the anti-inflammatory effects of SLPI. They noted that SLPI failed to suppress production of tumor necrosis factor- $\alpha$ (TNF $\alpha$ ), cytokine-induced neutrophil chemoattractant (CINC), and MIP-2 protein, despite the fact that it partially suppressed whole lung NF- $\mathrm{B}$ activation at 4 hours after administration of IgG immune complex. However, when they examined alveolar macrophages harvested at 30 minutes, they found that SLPI did not suppress NF- $\kappa$ B activation at all. These findings support the idea that different anatomic compartments may show quite different responses to both inflammatory agents and antiproteases.

Our results are also probably influenced by the short time span of our experiments. The anti-inflammatory effects of both these agents, at least as measured by $\mathrm{NF}-\kappa \mathrm{B}$ activation, seem to partially wear off by 24 hours, and increased gene expression for MIP-2 and 


\section{Western blot - 24 hrs -I $\kappa \mathrm{B} \alpha$}

Ctrl Silica $\quad$ Si+A1AT $\quad$ Si+RS113

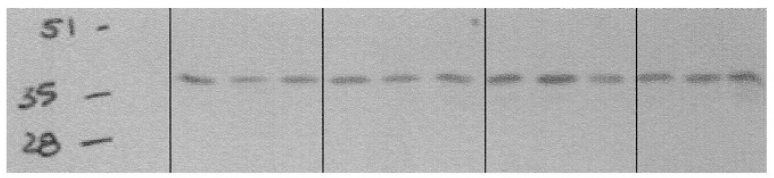

Effects of Protease Inhibitors on $\mathrm{lkBa}$ at 24 Hours

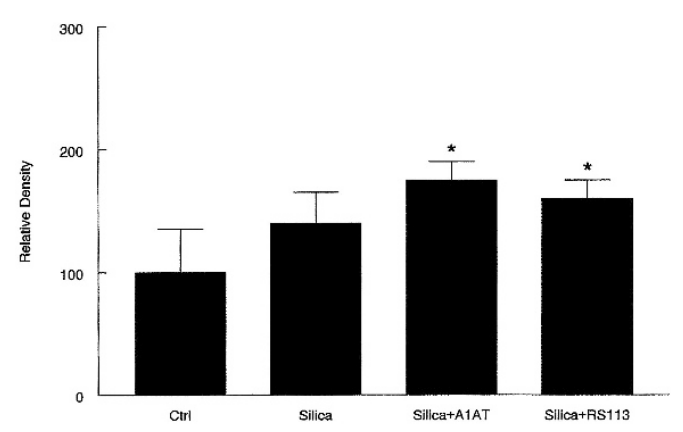

Western blot - 24 hrs - IאB $\beta$

Ctrl $\quad$ Silica $\quad$ Si+A1AT $\quad$ Si+RS113

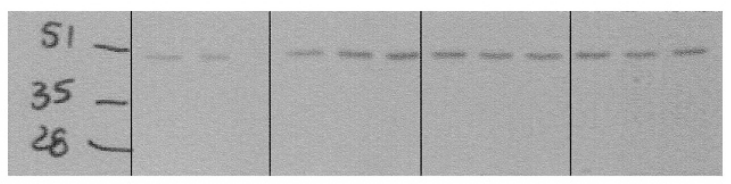

Figure 3.

Effects of $\alpha 1 \mathrm{AT}$ and RS113456 on $\mathrm{I}_{\kappa} \mathrm{B}$ levels at 24 hours in whole lung. $\mathrm{I}_{\kappa} \mathrm{B}$ levels have rebounded after treatment with silica alone and are elevated with both antiproteases. Values are mean $\pm \mathrm{SD} .{ }^{*}$ Significantly greater than control.

MCP-1 is evident, at least for $\alpha 1 \mathrm{AT}$ administration, by 24 hours.

In fact it is not at all clear whether MIP-2 and MCP-1 gene expression or protein production are actually relevant to the anti-inflammatory effects of antiproteases seen in our experiments. There is good evidence in the literature that $\alpha 1 \mathrm{AT}$ inhibits PMN migration, even in isolated cell models (Stockley et al, 1990), and we have observed a similar result with a synthetic metalloprotease inhibitor (A Churg, unpublished data). Thus the real protective process might be an inability of PMN to enter the lung, despite increased levels of chemoattractant proteins.

It is also useful to note that we find suppression of ICAM-1 protein, an NF- $\kappa \mathrm{B}-$ driven product (Hubbard and Rothlein, 2000), by both antiproteases. These findings, as opposed to the MIP-2/MCP-1 findings, are concordant in terms of $\mathrm{NF}-\kappa \mathrm{B}$ suppression and protein production. This again suggests that the system is complex, and that, at the least, different proteins involved in the inflammatory response show different patterns of suppression or production. Lentsch et al (1999) also found that SLPI prevented the increased levels of ICAM-1 (measured as vascular ICAM-1) ordinarily seen in their model. Their data and our data suggest that another possible mechanism for the decrease in neutrophil influx seen in the presence of elevated chemokine protein levels is a failure of vascular neutrophil adhesion secondary to a failure to up-regulate adhesion molecules.

There are also some notable inconsistencies between our study and the data of Lentsch et al (1999) on SLPI. They found that $\alpha 1 \mathrm{AT}$ failed to prevent whole lung NF- $\kappa$ B translocation when $1 \mathrm{mg}$ of protein was administered along with IgG in their immune complex model and concluded that $\alpha 1 \mathrm{AT}$ was not antiinflammatory in the same fashion as SLPI. Our data, which are based on the use of $20 \mathrm{mg}$ of $\alpha 1 \mathrm{AT}$, suggest that they may have chosen a dose of $\alpha 1 \mathrm{AT}$ that was too low to be effective. Likewise, Lentsch et al (1999) observed that TIMP-2 had no protective effect against whole lung NF- $\kappa \mathrm{B}$ activation, as opposed to our finding with RS113456.

It is difficult to know whether the detailed differences among SLPI, $\alpha 1 \mathrm{AT}, \mathrm{RS} 113456$, and TIMP-2 are really intrinsic to each agent or whether they really reflect different models of lung inflammation, different antiprotease doses, and different sampling times after antiprotease administration. What is remarkable, however, is the observation that, in a very broad sense, four structurally different antiproteases with at least two different broad target specificities all share the ability to suppress the acute inflammatory response. It is intriguing to note in this regard that Zheng et al (2000) recently found that another broad spectrum metalloprotease inhibitor, GM6001, seemed to sup- 


\section{NF- $\kappa \mathrm{B}$ Gel Shift Images and Densitometry}
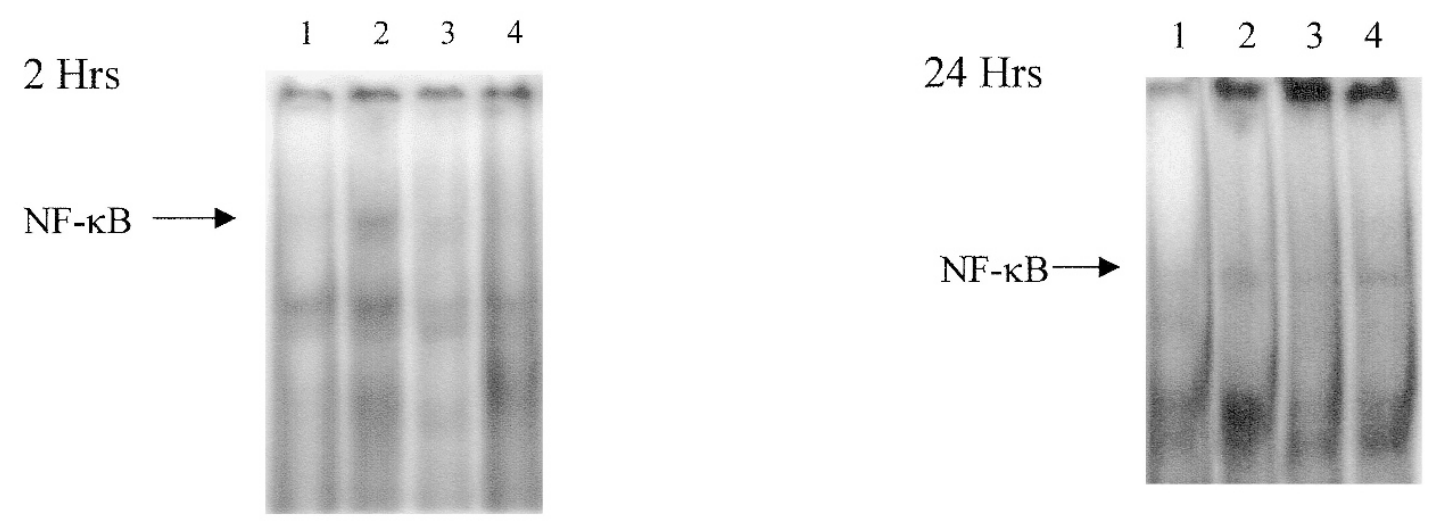

Effects of Protease Inhibitors on Nuclear NF-KB Levels 2 Hours After Silica Instillation
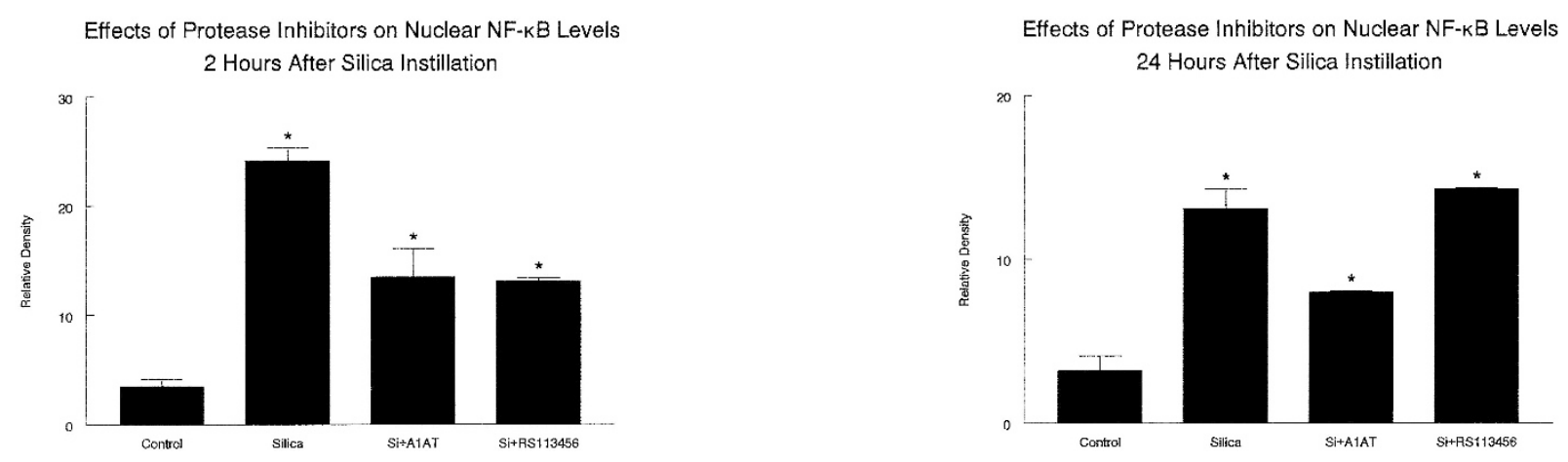

Figure 4.

Effects of $\alpha 1 \mathrm{AT}$ and RS113456 on nuclear translocation of NF- $\kappa$ B in whole lung. Silica produces a marked increase in NF- $\kappa$ B levels and this is about $50 \%$ suppressed by both antiproteases at 2 hours. At 24 hours, some protection is still present with $\alpha 1$ AT treatment. Lane 1, control; Lane 2, silica alone; Lane 3 , silica $+\alpha 1$ AT; Lane 4 , silica + RS113456.

press inflammation (but not metalloprotease production) in a model of IL-13-induced emphysema.

As noted above, how $\alpha 1 \mathrm{AT}$ and RS113456 might suppress the inflammatory response is unclear. Mulligan et al (2000) suggested that only SLPI mutants with antitrypsin activity suppressed inflammation and speculated that antiprotease activity involving the proteasome was important. To further investigate the need for antiproteolytic activity, we carefully oxidized our $\alpha 1 \mathrm{AT}$ samples until the antiproteolytic activity against neutrophil elastase had been almost completely destroyed. Although it is always difficult to be sure that the protein has not been damaged by such a maneuver, Western blot (Fig. 8) indicated that there was no obvious increase in the number or intensity of breakdown bands in the oxidized protein, so we have certainly not removed antiproteolytic activity by cleaving the protein into fragments. Nonetheless, this oxidized protein was just as effective as the original form in preventing the inflammatory influx and subsequent connective tissue breakdown. This finding suggests that, if $\alpha 1 \mathrm{AT}$ produces anti-inflammatory effects through an antiproteolytic mechanism, it is probably not one that involves the catalytic methionines at the traditional active site that inhibits most serine proteases. In this regard, there already exist data to indicate that different parts of the $\alpha 1 A T$ molecule possess quite different biologic properties: Banda et al (1988a, 1988b) reported that the low molecular weight fragments of $\alpha 1 \mathrm{AT}$, generated by complexing with neutrophil elastase or by macrophage metalloelastase attack, had chemoattractant rather than inflammatory suppressant properties.

Another possibility to be considered was that antiproteases prevented PMN influx by preventing matrix proteolysis by PMN-derived proteases and thus preventing the generation of chemotactic matrix fragments (Senior et al 1980, 1989). For this reason we administered silica to MME $-/-$ mice. These mice, as shown in Figure 9, develop an inflammatory response after silica administration but do not develop connective tissue breakdown. Beyond the lack of MME, the detailed mechanisms behind this phenomenon are unclear, but the fact that inflammation develops in the apparent absence of detectable elastin and collagen breakdown fragments indicates that it is not matrix 


\section{Gene Expression of MIP-2 and MCP-1 by RT-PCR}

2 Hours

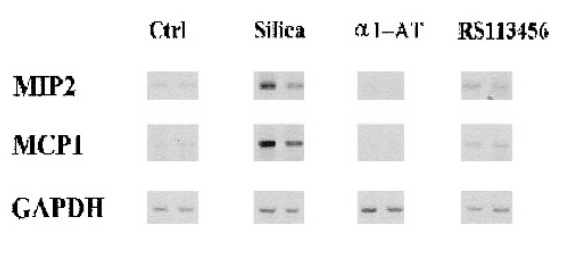

24 Hours

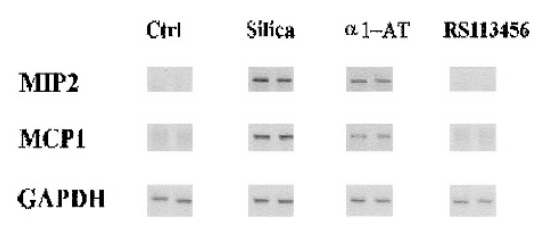

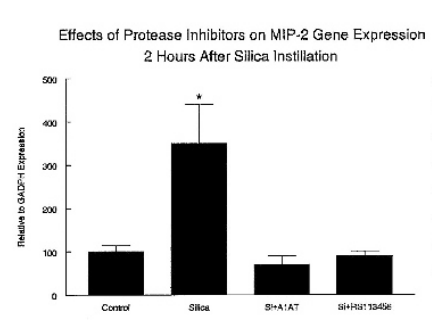
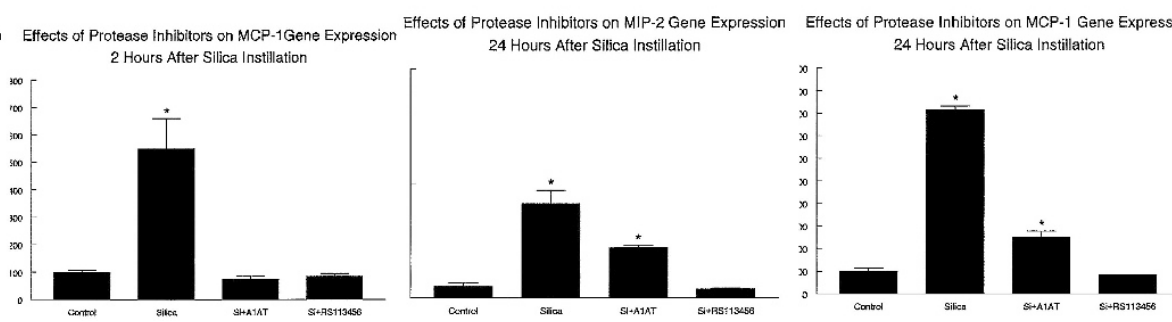

Figure 5.

Effects of $\alpha 1$ AT and RS113456 on gene expression of macrophage inflammatory protein-2 (MIP-2) and monocyte chemotactic protein-1 (MCP-1) at 2 and 24 hours in whole lung. Silica produces marked increases in MIP-2/MCP-1 levels. At 2 hours, both antiproteases suppress this increase completely; at 24 hours, antiprotease therapy is partially protective. Values are mean $\pm \mathrm{SD} .{ }^{*}$ Significantly greater than control.

fragment production that drives inflammation in this model. Of course, measurements of lavage desmosine and hydroxyproline are in some senses fairly crude measures, and we cannot rule out the possibility that a form of quantum (microscopic) proteolysis (Liou and Campbell, 1995), and therefore of quantum generation of chemoattractant matrix fragments, still occurs in these animals but is simply at too low a level to be detected by HPLC. But assuming that quantum generation of chemoattractant matrix fragments does not occur, the observation that the antiproteases are effective at suppressing inflammation in both normal and $\mathrm{MME}-1-$ mice suggests that their suppressive effects are probably not mediated via the classic type of antiproteolysis, because complexing of antiprotease to protease should prevent proteolysis and thus prevent formation of chemotactic matrix fragments. Our experiments showing that oxidized $\alpha 1$ AT that has lost its antiproteolytic activity still is anti-inflammatory, as described above, also support the notion that the classic process of antiproteolysis is not playing a role.

The conclusion of our study is that both PMN influx and connective tissue breakdown in the lung are prevented by $\alpha 1 \mathrm{AT}$ and RS113456. As noted in the introduction (para. 3), we have previously shown that there is an excellent correlation between suppression of PMN infiltration and suppression of connective tissue breakdown in acute models of both cigarette smoke and silica-induced disease (Dhami et al, 2000; Zay et al, 1999). Thus, antiprotease therapy in the current model using $\alpha 1 \mathrm{AT}$ seems to be producing a favorable endpoint. However, metalloprotease inhibi- tion seems to have the same effect. Hautamaki et al (1997), using MME -/- mice and cigarette smoke, also found a favorable endpoint, because MME -/mice were protected against smoke-induced emphysema. In the present study, RS113456 was just as effective as $\alpha 1 \mathrm{AT}$ in suppressing inflammation and connective tissue breakdown after silica exposure, and we have previously observed the same effect with cigarette smoke (A Churg, unpublished data).

All these observations describe a phenomenon reminiscent of that recently reported by Liu et al (2000) in a model of bullous pemphigoid. In that model, use of mice with either the neutrophil elastase or the Gelatinase B (MMP-9, a major neutrophil matrix metalloproteinase [MMP]) gene knocked out prevented the development of the characteristic blistering skin lesions, and this protection was associated with protection of endogenous $\alpha 1 \mathrm{AT}$ as shown by the appearance/ disappearance of a lower molecular weight breakdown band on Western blot. Reconstituting the neutrophil phenotype by adding cells with the missing protease led to the breakdown of $\alpha 1 \mathrm{AT}$ and the appearance of lesions, and conversely, adding exogenous $\alpha 1$ AT prevented the lesions. The authors concluded that Gelatinase B acts to regulate neutrophil elastase activity by cleaving $\alpha 1 \mathrm{AT}$.

Because both gelatinase $B$ and MME can degrade $\alpha 1$ AT (Shapiro, 1994), we hypothesized that our observations, and perhaps those of Hautamaki et al (1997), might be explained on the basis of the idea that protection against conditions mediated (at least acutely) by neutrophil influxes may be achieved by 
Antiprotease Effects After Silica Exposure - 2 Hours

Whole Lung MIP-2 (pg/g tissue)

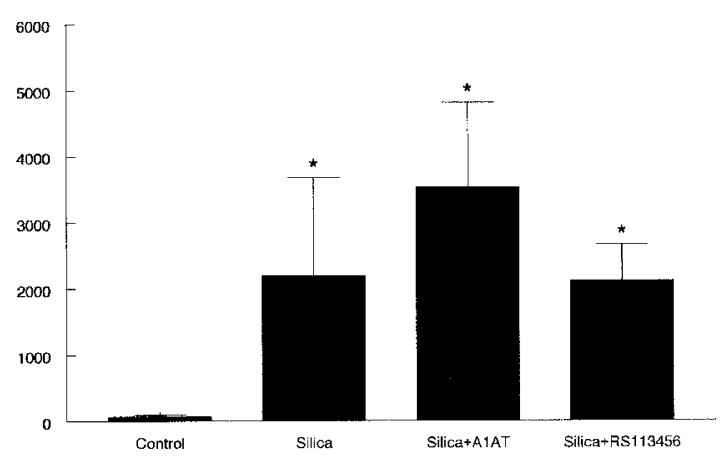

Antiprotease Effects After Silica Exposure -24 Hours Whole Lung MIP-2 (pg/g tissue)

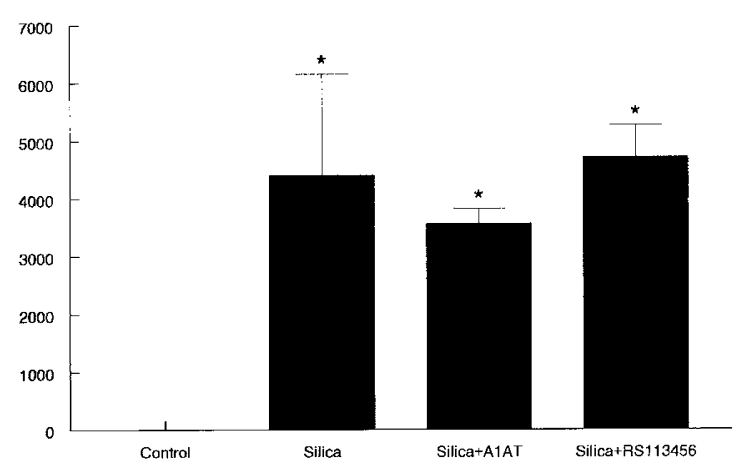

Antiprotease Effects After Silica Exposure -2 Hours

Whole Lung MCP-1 (pg/g tissue)

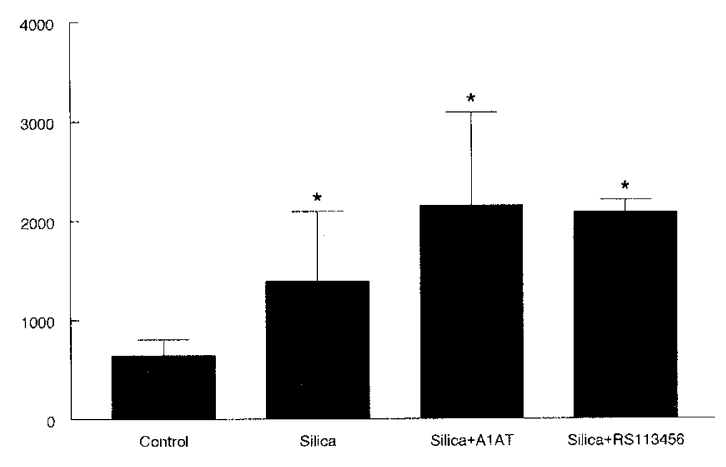

Figure 6.

Effects of $\alpha 1$ AT and RS113456 on levels of MIP-2 and MCP-1 protein in whole lung. Silica increases protein levels at both time points and neither antiprotease is protective. Values are mean $\pm \mathrm{SD} .{ }^{*}$ Significantly greater than control.

removing a portion of the MMP burden (either Gelatinase $B$ from PMN or MME from MAC) to protect endogenous $\alpha 1 \mathrm{AT}$, or by boosting effective $\alpha 1 \mathrm{AT}$ levels using exogenous protein. Unfortunately, our attempts to show this process, which might also explain the lack of connective tissue breakdown in the MME -/- mice, have not been successful thus far. There was no evidence on Western blot that endogenous $\alpha 1 \mathrm{AT}$ was protected in silica-treated MME -/mice compared with silica-treated $\mathrm{MME}+/+$ animals (Fig. 10), or compared with silica-treated C57 mice (data not shown). Additionally, we exposed C57 mice to silica or silica after treatment with RS113456 and found no differences in the pattern of breakdown fragments of endogenous $\alpha 1 \mathrm{AT}$ (data not shown). Thus, protection of $\alpha 1 \mathrm{AT}$ by removing MMP-mediated $\alpha 1$ AT breakdown does not seem to explain our results.

\section{Materials and Methods}

\section{Mouse Model of Silica-Induced Inflammation}

C57 BL/6 mice or macrophage metalloelastase knockout mice (MME -/-, see below), weighing approximately $30 \mathrm{~g}$, were administered a single $7 \mathrm{mg}$ dose of crystalline silica ( $\alpha$-quartz, Minusil-5; US Silica
Corporation, Clarkstown, West Virginia) in $0.1 \mathrm{ml}$ saline. This dose of silica produces a rapid and persisting acute inflammatory infiltrate. The MME $-/-$ mice were originally created in line 129 stock (Hautamaki et al, 1997), but because 129 strain mice show minimal responses to dust (Brass et al, 1999), they were bred back through 5 generations into C57 BL/6 stock. All MME -/- mice used in these experiments were C57 based. In some experiments C57-based generation 5 MME +/+ mice, derived through the same breeding process, were also used as a control group.

\section{Protease Inhibitors}

$\alpha 1$ AT (Prolastin) was purchased from Bayer (Etobicoke, Ontario, Canada) and administered at a dose of $20 \mathrm{mg} / \mathrm{animal}$ by ip injection 24 hours before dust administration. We have previously shown that this procedure boosts serum $\alpha 1$ AT by 2 to 3 times (Dhami et al, 2000). The broad spectrum metalloprotease inhibitor RS113456 was obtained from Roche Bioscience (Palo Alto, California) and was administered by gavage at a dose of $0.1 \mathrm{mg} / \mathrm{g} 1$ hour before dust administration following the manufacturer's guidelines. Details of the inhibitory profile of this compound are available in the article by Abbruzzese et al (1998). 


\section{Western Blots and Densitometry for Whole Lung ICAM-1}

\section{Hours}
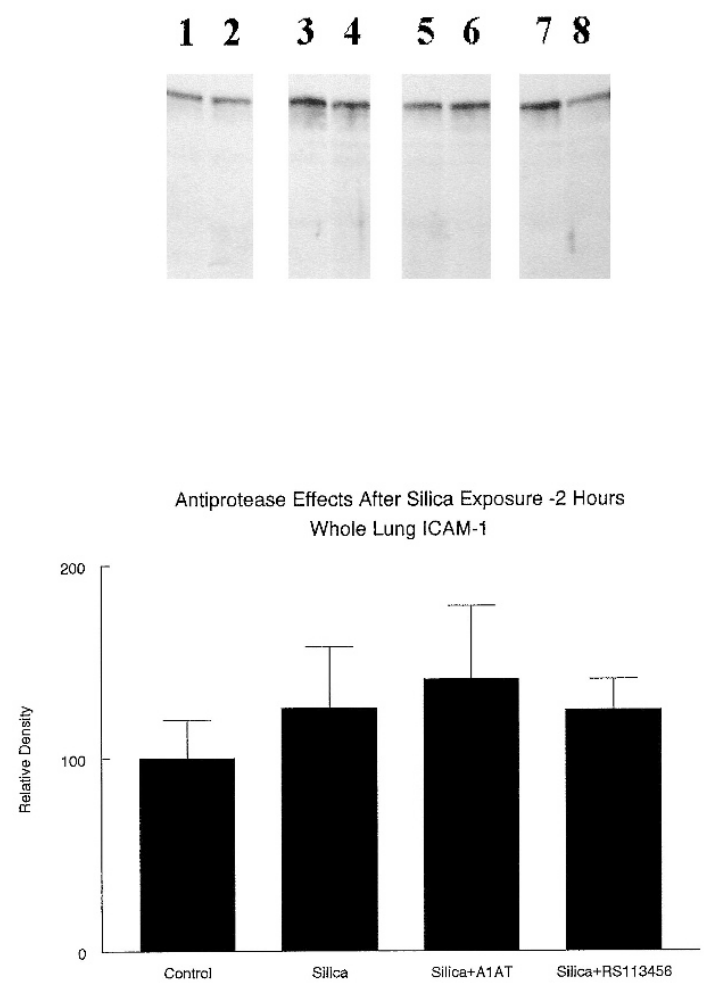

24 Hours

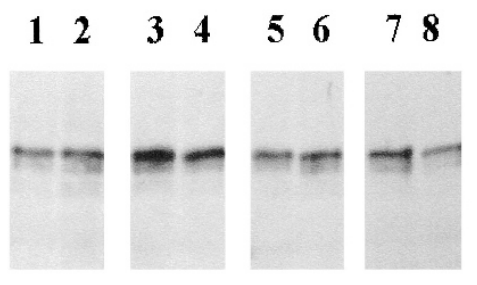

Figure 7.

Effects of $\alpha 1$ AT and RS113456 on levels of intercellular adhesion molecule-1 (ICAM-1) protein in whole lung. No treatment changes ICAM-1 levels at 2 hours, but at 24 hours, silica produces a small increase, and this is blocked by both antiproteases. Values are mean \pm sD. * Significantly greater than control.

\section{Lavage for Cell Counts and Proteins}

Mice were euthanized 2 or 24 hours after dust exposure by halothane overdose and the lungs removed from the chest cavity. A 20-gauge catheter was inserted into the trachea and the lungs lavaged six times, with $1 \mathrm{ml}$ of ice-cold saline for cell counts or $\alpha 1 \mathrm{AT}$ levels, or with distilled water for connective tissue degradation analysis. Separate sets of animals were used for these latter experiments. The water lavage is necessary because concentration of salts from saline lavage during sample preparation for the HPLC procedure interferes with the analysis of desmosine (Li et al, 1996).

For inflammatory cell measurements, the saline lavage was centrifuged at $200 \times g$ at $4^{\circ} \mathrm{C}$ for $10 \mathrm{~min}-$ utes. The supernatants were decanted, and the cell pellets were resuspended in $200 \mu$ l of saline. Total cell counts were performed in a hemacytometer and differential cell counts were performed on a 10- $\mu$ l drop of the cell suspension heat-fixed on a slide and stained with hematoxylin-eosin.

\section{Desmosine and Hydroxyproline Analysis}

The water lavageate was lyophilized and hydrolyzed in $\mathrm{HCl}$ at $110^{\circ} \mathrm{C}$ for 48 hours and then analyzed for desmosine (DES) and hydroxyproline (HP) on a Waters HPLC system (Waters Associates, Milford, Massachusetts) using our previously published protocol (Li et al, 1996).

\section{Lavage Western Blots for $\alpha 1 A T$}

Freshly collected lavage samples (approximately $8 \mathrm{ml}$ each) were kept on ice, and the following antiproteinases were added to the solution: $1 \mathrm{~mm}$ EDTA, $0.5 \mathrm{~mm} 4-(2-$ aminoethyl)-benzensulfonyl fluoride hydrochloride (AEBSF), $1 \mu \mathrm{g} / \mathrm{ml}$ leupeptin, $1 \mu \mathrm{g} / \mathrm{ml}$ aprotinin, $10 \mu \mathrm{g} / \mathrm{ml}$ trypsin-chymotrypsin inhibitor, $1 \mu \mathrm{g} / \mathrm{ml}$ pepstatin A (all from Sigma, St. Louis, Missouri). Lavage samples were lyophilized and reconstituted in $2 \mathrm{ml}$ distilled water, aliquoted, and kept at $-80^{\circ} \mathrm{C}$ until used. Proteins were resolved on $12 \%$ polyacrylamide gel under reducing conditions using a 1-mm gel thickness and loading a 25- $\mu$ l sample in each well. Protein bands were immobilized on nitrocellulose membrane (BioRad Laboratories, Hercules, California) and blocked with 5\% skim milk solution in PBS buffer. After blocking, the membrane was incubated in 5\% skim milk solution in PBS containing 1:1000 dilution of polyclonal anti-human alpha-1 antitrypsin antibody (ICN Biochemicals, Cleveland, Ohio). After three washes, the membrane was incubated 


\section{Effects of Oxidized $\alpha 1 \mathrm{AT}$ on Inflammatory Cell Influx}

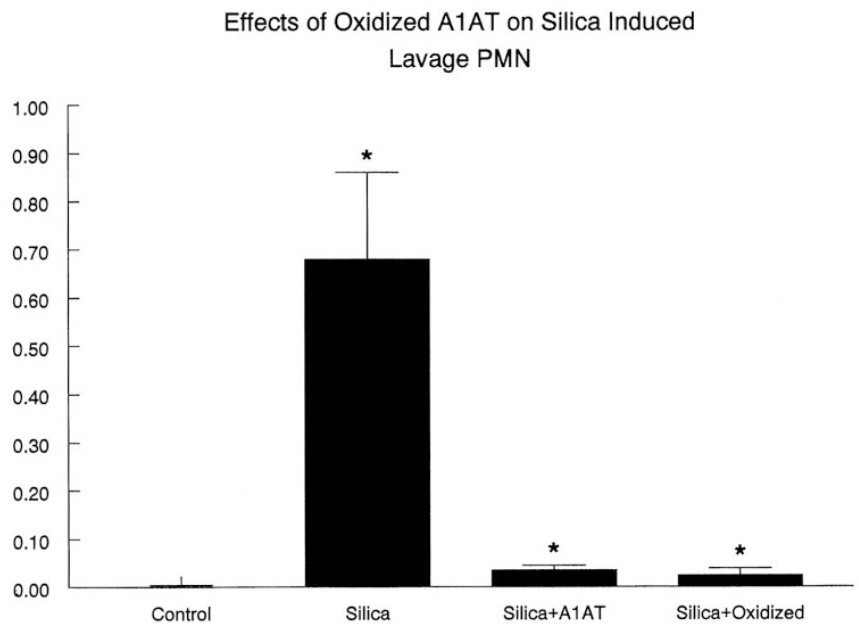

Western Blot for Human Alpha1-Antitrypsin (Prolastin)

Original Oxidized

Figure 8.

Effects of oxidized $\alpha 1$ AT. Oxidized $\alpha 1$ AT, prepared as described in the text, protects against silica-induced lavage PMN influx to the same extent as the original unoxidized product. Oxidized $\alpha 1$ AT does not affect macrophage (MAC) levels in lavage (data not shown). The Western blot for $\alpha 1 \mathrm{AT}$ shows that the pattern of breakdown bands is not changed by oxidation as described in the text, indicating that oxidation has not broken up the protein. Values are mean \pm SD. ${ }^{*}$ Significantly greater than control.

in a 5\% skim milk solution in PBS containing 1:2000 dilution of horse radish peroxidase (HRP)-labeled antigoat IgG (R\&D Systems, Minneapolis, Minnesota). Protein bands were detected with a chemiluminescence reaction ( $E C L)$ kit (Amersham, Arlington Heights, Illinois) and exposed to X-ray film (Kodak, New Haven, Connecticut).

\section{Western Blots for IкB}

Animals were euthanized, and unlavaged lung was snap frozen. Frozen lung tissue was homogenized in a solution of $0.1 \%$ Triton $X-100,150 \mathrm{~mm} \mathrm{NaCl}, 10 \mathrm{~mm}$ HEPES (pH 7.5), 1 mm EDTA, 0.5 mm AEBSF, $1 \mu \mathrm{g} / \mathrm{mL}$ leupeptin, $1 \mu \mathrm{g} / \mathrm{mL}$ aprotinin, $10 \mu \mathrm{g} / \mathrm{mL}$ soybean trypsin inhibitor, and $1 \mu \mathrm{g} / \mathrm{mL}$ pepstatin $A$. The homogenate was incubated on ice for 5 minutes and then centrifuged at 5000 rpm for 5 minutes. The nuclear pellet was collected for gel shift assay (see below). A protein assay was carried out on the supernatant and equal amounts of protein were used for each sample. The samples were separated in a $12 \%$ polyacrylamide gel and transferred to nitrocellulose membranes. The membranes were incubated in tris-buffered saline (TBS) containing 0.05\% Tween-20 and 5\% skim milk powder for 18 hours at $4^{\circ} \mathrm{C}$. The membranes were then incubated in a 1:400 dilution of rabbit polyclonal anti- $I_{\kappa} \mathrm{B} \alpha$ or $I_{\kappa} \mathrm{B} \beta$ (Santa Cruz Biotechnology, Santa Cruz, California) in TBS with $0.05 \%$ Tween-20 and 5\% skim milk powder. The membranes were washed three times in TBS with $0.05 \%$ Tween-20 and incubated in a 1:1000 dilution of horseradish peroxidase-conjugated goat anti-rabbit IgG (ICN Biochemicals). Detection was by chemiluminescence, and densitometry was performed on the films.

\section{NF-кB Gel Shift Assay}

The pelleted nuclei from the procedure above were resuspended in 100 to $500 \mu \mathrm{L}$ of $25 \%$ glycerol, $20 \mathrm{~mm}$ HEPES, $420 \mathrm{~mm} \mathrm{NaCl}, 1.2 \mathrm{~mm} \mathrm{MgCl}_{2}, 0.2 \mathrm{~mm}$ EDTA, $0.5 \mathrm{~mm}$ dithiothreitol (DTT), $0.5 \mathrm{~mm}$ AEBSF, $1 \mu \mathrm{g} / \mathrm{ml}$ leupeptin, $1 \mu \mathrm{g} / \mathrm{ml}$ aprotinin, $10 \mu \mathrm{g} / \mathrm{ml}$ soybean trypsin inhibitor, $1 \mu \mathrm{g} / \mathrm{ml}$ pepstatin $A$, and left on ice for a 30-minute high salt extraction of the nuclear proteins. The lysed nuclei were centrifuged at 2000 rpm for 15 seconds, and a protein assay was carried on the supernatant. Single-stranded NF-B consensus oligonucleotide (5' -AGT TGA GGG GAC TTT CCC AGG C - 3') was end-labeled with $\left[\gamma^{-}{ }^{32} P\right]$ ATP. Binding reactions containing equal amounts of protein $(7 \mu \mathrm{g})$ and $6.7 \mathrm{pmol}$ of oligonucleotide were performed for 20 minutes in binding buffer (10 mM Tris $\mathrm{HCl}, 50 \mathrm{~mm} \mathrm{NaCl}$, $1 \mathrm{~mm}$ EDTA, 4\% glycerol, $67 \mu \mathrm{g} / \mathrm{ml}$ poly[dl-dC]). Reaction products were separated in a $5 \%$ polyacrylamide gel in $0.25 \times$ TBE buffer and analyzed by autoradiography and densitometry.

\section{Expression of Inflammatory Mediators by RT-PCR}

RNA was extracted from whole lung by the method of Chomczynski and Sacchi (1987). First strand cDNA was synthesized using superscript Rnase $\mathrm{H}$ reverse transcriptase (GIBCO-BRL, Grand Island, New York) according to the manufacturer's instruction. Briefly, 5 $\mu \mathrm{g}$ RNA were added to a reaction mixture of $1 \times$ first strand buffer; $200 \mathrm{ng}$ oligo(dT)12-18 primer; $0.5 \mathrm{~mm}$ each of dATP, dTTP, dGTP, and dCTP; $0.1 \mathrm{M} \mathrm{DTT;}$ plus water to $49 \mu \mathrm{l}$. Superscript RT (200 U) was added, and the reaction was incubated at $42^{\circ} \mathrm{C}$ for 1 hour. 
Effects of Silica and Antiproteases in Macrophage Metalloelastase Knockout Mice

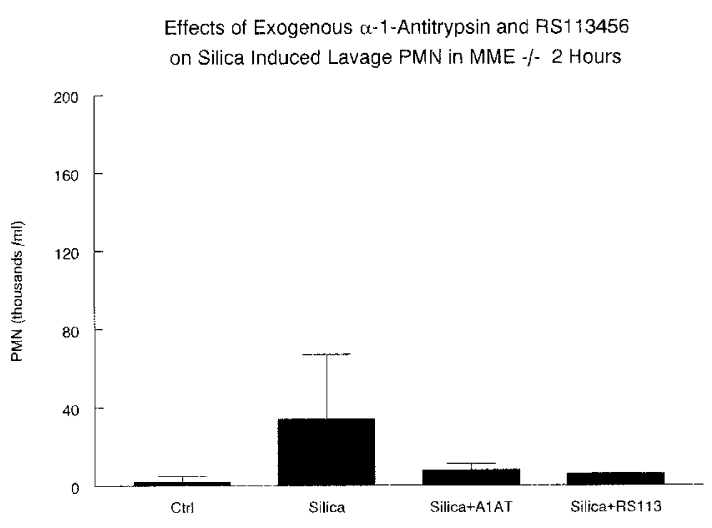

Effects of $\alpha 1$ AT and RS113456 on Silica Induced Lavage Desmosine in MME-/. Mice at $24 \mathrm{Hrs}$

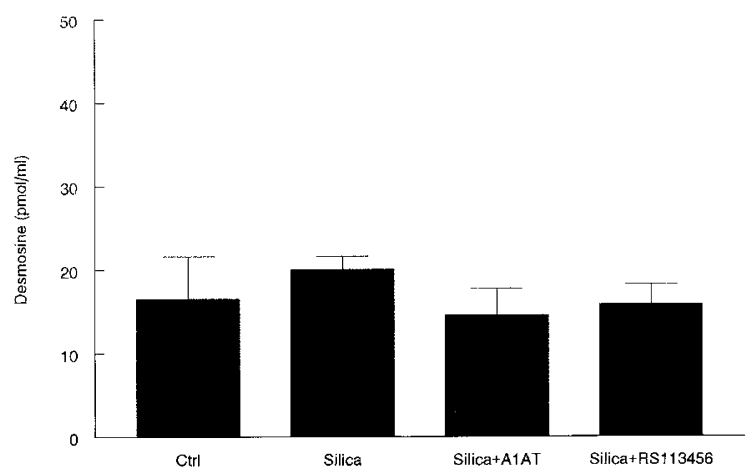

Effects of Exogenous $\alpha$-1-Antitrypsin and RS113456 on Silica Induced Lavage PMN in MME $\% 24$ Hours

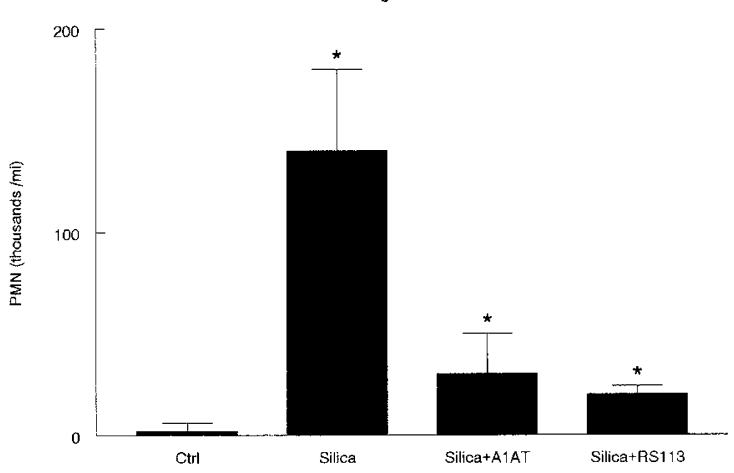

Effects of $\alpha 1$ AT and RS113456 on Silica Induced Lavage Hydroxyproline in MME- $/$ Mice at $24 \mathrm{Hrs}$

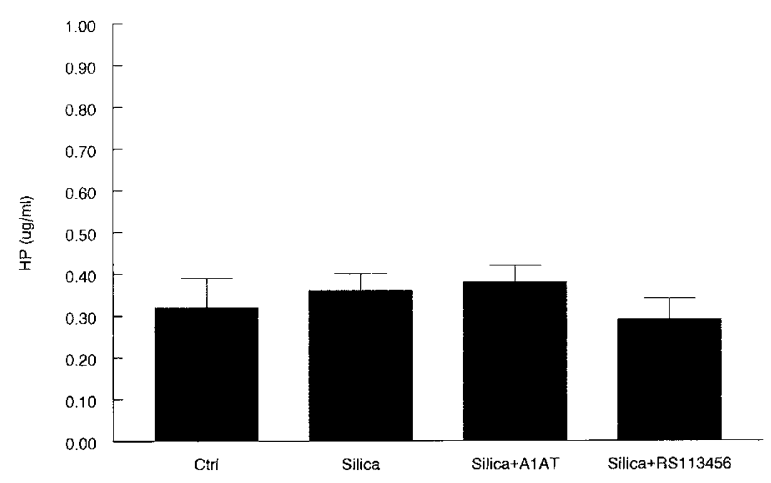

Figure 9.

Effects of $\alpha 1 \mathrm{AT}$ and RS113456 in macrophage metalloelastase (MME) - /- mice. Silica induces a lavage neutrophilia in these mice, and both antiproteases nearly completely block the influx. However, lavage desmosine and hydroxyproline are never elevated in these animals. These findings suggest that the PMN influx after silica exposure is not mediated through generation of chemoattractant matrix fragments and that classic antiproteolysis (complexing of the protease and antiprotease) is not playing a role in the suppressive effects of antiproteases. Values are mean \pm SD. ${ }^{*}$ Significantly greater than control.

PCR reactions contained $1 \mu \mathrm{M}$ primers, $1.5 \mathrm{~mm}$ $\mathrm{Mg}^{++}, 200 \mu \mathrm{M}$ deoxynucleotide triphosphates, reaction buffer, $2.5 \mathrm{U}$ of Taq DNA polymerase (PerkinElmer Cetus Instruments, Norwalk, Connecticut) and 1 or $5 \mu \mathrm{l}$ of cDNA in a final volume of $20 \mu \mathrm{l}$. The PCR temperature profile consisted of 25 or 28 cycles of denaturation at $94^{\circ} \mathrm{C}$ for 45 seconds, primer annealing at $60^{\circ} \mathrm{C}$ for 45 seconds, and extension at $72^{\circ} \mathrm{C}$ for 1.25 minutes, followed by an additional 5 minutes final extension at $72^{\circ} \mathrm{C}$. The PCR products were size fractionated on $1.5 \%$ agarose gel and quantified from this ethidium bromide-stained gel using a gel documentation system (BioRad Laboratories).

Primer design was based on sequences from the Genbank database with glyceraldehyde-3-phosphate dehydrogenase (GAPDH) as the reference gene:

Sense GADPH 5' CGG ATT TGG CCG TAT TGG GC Antisense GADPH 3' TGA TGG CAT GCA CTG TGG TC Sense MIP-2 5' GGC ACA TCA GGT ACG ATC CAG Antisense MIP-2 3' ACC CTG CCA AGG GTT GAC TTC Sense MCP-1 5' GCC CAG GAC CAG CAC CAG Antisense MCP-1 3' GGC ATC ACA TGC CGA GTC ACA C
We optimized the reaction conditions (magnesium concentration, thermocycler temperature, etc.) to produce the greatest amount of a single PCR product. The amount of cDNA used and number of cycles of amplification were adjusted to stay within the linear region of amplification to allow quantification. Specificity of the various products was confirmed by restriction digests.

\section{Measurement of MIP-2, MCP-1, and ICAM-1 Protein Levels}

Measurement was carried out using ELISA kits from R\&D Systems for murine MIP-2 and from BioSource International (Camarillo, California) for murine MCP-1. Lungs were homogenized under liquid nitrogen, and the powder was resuspended in $500 \mu$ l lysing solution on ice for 20 minutes. The lysing solution contained 10 mm HEPES (pH, 7.5), 0.5\% Triton X-100, $150 \mathrm{~mm}$ $\mathrm{NaCl}, 1 \mathrm{~mm}$ EDTA, $0.5 \mathrm{~mm}$ AEBSF, $1 \mu \mathrm{g} / \mathrm{ml}$ leupeptin, $1 \mu \mathrm{g} / \mathrm{ml}$ aprotinin, $10 \mu \mathrm{g} / \mathrm{ml}$ trypsin-chymotrypsin inhibitor, and $1 \mu \mathrm{g} / \mathrm{ml}$ pepstatin A (all reagents from Sigma). The samples were then centrifuged at 14,000 rpm for 10 minutes at $4^{\circ} \mathrm{C}$, and the supernatants were 


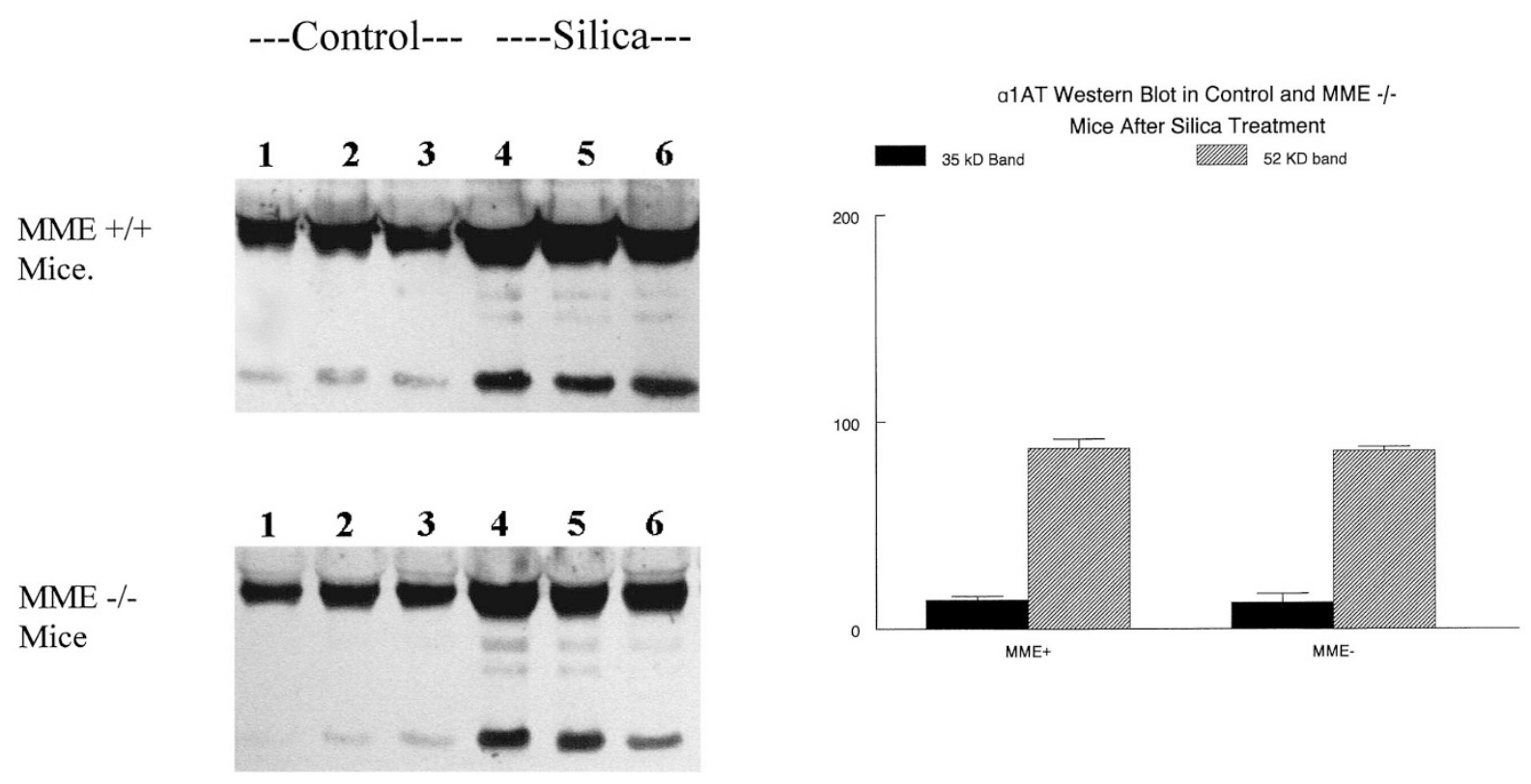

Figure 10.

Silica exposure induces leakage of $\alpha 1 \mathrm{AT}$ into the lung and is associated with $\alpha 1 \mathrm{AT}$ breakdown, visible as the $35 \mathrm{kd}$ lower band on the Western blot using antibody against $\alpha 1 \mathrm{AT}$. There is no protection against $\alpha 1 \mathrm{AT}$ breakdown in MME $-/-$ mice. This experiment uses MME $+/+$ as the control group, but identical results were obtained with C57 mice.

decanted and kept on ice. TGF $\beta$ was activated by adding $500 \mu \mathrm{l} 2.5 \mathrm{~N}$ acetic acid/10 M urea solution to $500 \mu$ l supernatant. This mixture was incubated at room temperature for 10 minutes and then neutralized with $2.7 \mathrm{~N} \mathrm{NaOH} / 1 \mathrm{M} \mathrm{HEPES}$. ELISA was then performed according to the manufacturer's instructions. ICAM-1 levels were analyzed on the same lung homogenate by Western blot using an antibody purchased from Santa Cruz Biotechnology.

\section{Oxidative Inactivation of $\alpha 1 A T$ (Prolastin) Antiprotease Activity}

Using the product as purchased from Bayer, antielastase activity was detected with a colorimetric substrate, SAAAN (Sigma), and human neutrophil elastase (Calbiochem, San Diego, California). Series of dilutions were prepared from the freshly reconstituted Prolastin (1:2, 1:4, 1:8, 1:16, etc.). It was found that at the concentrations used, a 1:64 dilution of Prolastin was the last dilution where neutrophil elastase (NE) was 100\% inhibited by intact Prolastin. Prolastin was then inactivated by incubation with $0.01 \mathrm{M}$ hydrogen peroxide for 48 hours at $4^{\circ} \mathrm{C}$ on a shaker. Hydrogen peroxide was dialysed out of the solution with several changes of saline solution at $4^{\circ} \mathrm{C}$. The hydrogen peroxide content of the final product was tested with Catalase (Sigma). After hydrogen peroxide was no longer detectable, the concentration of the product was reinstated to the original level. The activity of the treated Prolastin was tested in the same way as the original product. It was found that the straight reconstituted stock showed about $30 \%$ of the elastase inhibitory capacity of untreated Prolastin, and even a 1:2 dilution of this stock had no anti-elastase activity at all.

To show that methionines had been oxidized by this procedure, the treated protein was first hydrolyzed in 4 $\mathrm{M}$ potassium hydroxide at $105^{\circ} \mathrm{C}$ for 16 hours. The hydrolysate was neutralized with $6 \mathrm{M}$ hydrochloric acid, and its amino acid composition was determined as follows: $50 \mu$ l samples were dried using a Waters PicoTag Vacuum Station (Waters Associates) and redried in $50 \mu$ of 2:1:1 ethanol:water:triethylamine (TEA). Dried samples were derivatized with $50 \mu$ l solutions of $7: 1: 1: 1$ ethanol:water:TEA:phenylisothiocyanate (PITC) for 20 minutes at room temperature. The derivatized samples were dried again and dissolved in $700 \mu \mathrm{l}$ phosphate buffer for analysis. Analysis was performed on the Waters HPLC system. Amino acid separation was achieved on a Partisil ODS-2 C18, $10 \mu \mathrm{m}, 4.6 \times 250 \mathrm{~mm}$ Whatman column (Whatman, Clifton, New Jersey). The mobile phase was programmed at a flow rate of $1.6 \mathrm{ml}$ per minutes starting with $100 \%$ solvent A $(60 \mathrm{ml}$ acetonitrile and $940 \mathrm{ml}$ of $138 \mathrm{~mm}$ acetate buffer, $\mathrm{pH} 6.4$, with $0.05 \%$ TEA), followed by a linear gradient to $50 \%$ solvent B (60\% acetonitrile in water) for an additional 15 minutes. The column was then cleaned with $100 \%$ solvent B for 12 minutes and equilibrated with $100 \%$ solvent $A$ for 
another 12 minutes before injection of the next sample. Absorbance was read at $254 \mathrm{~nm}$. The detection limit of methionine was $0.1 \mathrm{ng}$ with a $30-\mu \mathrm{l}$ injection with a signal-to-noise ratio of 5 . All operations were performed at room temperature.

\section{References}

Abbruzzese TA, Guzman RJ, Martin RL, Yee C, Karins CK, and Dalman RL (1998). Matrix metalloproteinase inhibition limits arterial enlargement in a rodent arteriovenous fistula model. Surgery 124:328-335.

Ashcroft GS, Li K, Jin W, Glongenecker G, Kulkarni AB, Greenwell-Wild T, Hale-Donze H, McGrady G, Song X-Y, and Wahl SM (2000). Secretory leukocyte protease inihibitor mediates non-redundant functions necessary for wound healing. Nat Med 6:1147-1153.

Banda MJ, Rice AG, Griffin GL, and Senior RM (1988a). The inhibitory complex of human $\alpha 1$-proteinase inhibitor and human leukocyte elastase is a neutrophil chemoattractant. $\mathrm{J}$ Exp Med 167:1608-1615.

Banda MJ, Rice AG, Griffin GL, and Senior RM (1988b). $\alpha 1$ proteinase inhibitor is a neutrophil chemoattractant after proteolytic inactivation by macrophage elastase. J Biol Chem 263:4481-4484.

Brass DM, Hoyle GW, Poovey HG, Liu JY, and Brody AR (1999). Reduced tumor necrosis factor-alpha and transforming factor beta1 expression in the lungs of inbred mice that fail to develop fibroproliferative lesions consequent to asbestos exposure. Am J Pathol 154:853-862.

Chleq-Deschamps CM, LeBrun DP, Huie P, Besnier DP, Warnke RA, Sibley RK, and Cleary ML (1993). Topographic dissociation of BCL-2 messenger RNA and protein expression in human lymphoid tissues. Blood 81:293-298.

Chomczynski P and N Sacchi (1987). Single-step method of RNA isolation by acid guanidinium thiocyanate-phenolchloroform extraction. Anal Biochem 162:156-159.

Dhami R, Gilks B, Zie C, Zay K, Wright JL, and Churg A (2000). Acute cigarette smoke-induced connective tissue breakdown is mediated by neutrophils and prevented by $\alpha 1$-antitrypsin. Am J Respir Cell Mol Biol 22:244-252.

Hautamaki R, Kobayashi D, Senior R, and Shapiro S (1997). Requirement for macrophage elastase for cigarette smokeinduced emphysema in mice. Science 277:2002-2004.

Hubbard AK and Rothlein R (2000). Intercellular adhesion molecule-1 (ICAM-1) expression and cell signaling cascades. Free Radic Biol Med 28:1379-1386.

Janssen-Heininger YMW, Poynter ME, and Baeuerle PA (2000). Recent advances towards understanding redox mechanisms in the activation of nuclear factor $\kappa \mathrm{B}$. Free Radic Biol Med 9:1317-1327.

Jin FY, Nathan C, Radzioch D, and Ding A (1997). Secretory leukocyte protease inhibitor: A macrophage product induced by and antagonistic to bacterial lipopolysaccharide. Cell 88:417-426.

Kikuchi T, Abe T, Yaeiashiwa M, Tominaga Y, Mitsuhashi H, Satoh K, Nakamura T, and Nukiwa T (2000). Secretory leukoprotease inhibitor augments hepatocyte growth factor production in human lung fibroblasts. Am J Respir Cell Mol Biol 23:364-370.
Lentsch AB, Jordan JA, Czermak BJ, Diehl KM, Younkin EM, Sarma V, and Ward PA (1999). Inhibition of NF- $\kappa B$ activation and augmentation of $I_{\kappa} B \beta$ by secretory leukocyte protease inhibitor during lung inflammation. Am J Pathol 154:239-247.

Li K, Keeling B, and Churg A (1996). Mineral dusts cause collagen and elastin breakdown in the rat lung: A potential mechanism of dust-induced emphysema. Am J Respir Crit Care Med 153:644-649.

Liou TG and Campbell EJ (1995). Nonisotrophic enzymeinhibitor interactions: A novel nonoxidative mechanism for quantum proteolysis by human neutrophils. Biochemistry 34:16171-16177.

Liu Z, Zhou X, Shapiro SD, Shipley JM, Twining SS, Diaz LA, Senior RM, and Werb Z (2000). The serpin $\alpha 1$-proteinase inhibitor is a critical substrate for gelatinase B/MMP-9 in vivo. Cell 109:647-655.

Mulligan MS, Desrochers PE, Chinnaiyan AM, Gibbs DF, Warani J, Johnson KJ, and Weiss SJ (1993). In vivo suppression of immune complex-induced alveolitis by secretory leukoproteinase inhibitor and tissue inhibitor of metalloproteinases 2. Proc Natl Acad Sci USA 90:11523-11527.

Mulligan MS, Lentsch AB, Huber-Lang M, Guo R-F, Sarma V, Wright CD, Ulich TR, and Ward PA (2000). Anti-inflammatory effects of mutant forms of secretory leukocyte protease inhibitor. Am J Pathol 156:1033-1039.

Schins RPF, McAlinden A, MacNee W, Jimenex A, Ross JA, Guy K, Faux SP, and Donaldson K (2000). Persistent depletion of I Kappa B Alpha and interleukin-8 expression in human pulmonary epithelial cells exposed to quartz particles. Toxicol Appl Pharmacol 167:101-117.

Senior RM, Griffin GL, and Mecham RP (1980). Chemotactic activity of elastin-derived peptides. J Clin Invest 66: 859-862.

Senior RM, Hinek A, Griffin GL, Pipoly DJ, Courch EC, and Mecham RP (1989). Neutrophils show chemotaxis to type IV collagen and its $7 S$ domain and contain a $67 \mathrm{kD}$ type IV collagen binding protein with lectin properties. Am J Respir Cell Mol Biol 1:479-487.

Shapiro SD (1994). Elastolytic metalloproteinases produced by human mononuclear phagocytes. Am J Respir Crit Care Med 150:S160-S164.

Stockley RA, Shaw J, Afford SC, Morrison HM, and Burnett D (1990). Effect of $\alpha$-1-proteinase inhibitor on neutrophil chemotaxis. Am J Respir Cell Mol Biol 2:163-170.

Zhang Y, DeWitt DL, McNeely TB, Wahl SM, and Wash LM (1997). Secretory leukocyte protease inhibitor suppresses the production of monocyte prostaglandin $\mathrm{H}$ synthase-2, prostaglandin E2, and matrix metalloproteinases. J Clin Invest 99:894-900.

Zheng T, Zhu Z, Wang Z, Homer RJ, Ma B, Riese RJ, Chapman HA, Shapiro SD, and Elias JA (2000). Inducible targeting of $\mathrm{IL}-13$ to the adult lung causes matrix metalloproteinase- and cathepsin-dependent emphysema. J Clin Invest 106:1081-1093.

Zay K, Loo S, Xie C, Devine DV, Wright J, and Churg A (1999). The role of neutrophils and $\alpha$-1-antitrypsin in coal and silica-induced connective tissue breakdown. Am J Physiol 276:L269-L279. 